\title{
TEMPORAL 'SINCE’ IN SLOVAK: CONJUNCTION(S) AND ASPECT CHOICE - A CORPUS STUDY
}

\author{
PAULA KYSELICA - RENÉ M. GENIS \\ University of Amsterdam, The Netherlands
}

\begin{abstract}
KYSELICA, Paula - GENIS, M. René: Temporal 'since' in Slovak: conjuction(s) and aspect choice - a corpus study. Journal of Linguistics, 2019, Vol. 70, No 2, pp. 200 -215 .
\end{abstract}

\begin{abstract}
It has recently been shown by especially [1] through [4] and [12] for Russian and by [8] and [9] for Polish that conjunctions corresponding to Dutch sinds (cf. also [1], [2], [3]) and English since (cf. also [7], [10]) have temporal functions, which are subject to restrictions on the choice of tense and aspect. Ultimately these restrictions can be related to the semantic input of tense and aspect into complex sentences with these connective items. For Polish extensive data provided by corpus research enabled us to shed light on the usage and restrictions in this area and also to establish which constellations with particular conjunctions are more or less likely or not possible (cf. [8], [9]). In the present contribution we present freshly sourced quantitative Slovak SNKcorpus data. We consider the sixteen logically possible tense-aspect constellations, and the Slovak connective items: odkedy; odvtedy, čo / ako; od chvile, ked' / čo / ako; od tých čias, čo / ako; od tej doby, čo / ako. This quantitative data study is intended to pinpoint the areas of future research; for this purpose at certain instances comparisons are made with Polish, the only other language we have such data for to date.
\end{abstract}

Keywords: conjunction, tense, aspect, anteriority, simultaneity, taxis, Slovak, Polish

\section{INTRODUCTION}

This contribution presents the finding of our investigation into the Slovak corrrespon dences of Dutch and English temporal conjunctions, respectively sinds/ sedert and since and the tense-aspect (hereafter TA) constellations of the complex sentences they appear in. The underlying research is part of the ongoing taxis project of the research group "Comparative Slavic Verbal Aspect" at the university of Amsterdam. ${ }^{1}$ Our research group usually work within a cognitive-structuralist framework. Earlier research on this particular conjunction included Czech, Polish and Russian.

1 Cf. https://aclc.uva.nl/content/research-groups/comparativeslavic-verbal-aspect-and-related-issues/comparative-slavic-verbalaspect-and-related-issues.html ?origin=8ZtCo6Mj S\%2B6atiMzaszh6A. 


\subsection{Setting the scene}

The following example is in a few ways very typical of the kind of complex sentence we are dealing with.

(1) Odkedy t’a stretol, všetko sa zmenilo. [LŠti3] ${ }^{2}$

Since you.ACC meet.M.3SG.PST.PFV, everything REFL change.N.3SG.PST.PFV ${ }^{3}$

'Since he (had/has) met you, everything (had/has) changed.'

We see here the three noteworthy distinctive elements.

- the Secondary Clause (hereafter SC) Odkedy t'a stretol with conjugated verb stretol and

- 'since'-connective item odkedy;

- the Main Clause (hereafter MC) with conjugated verb zmenilo.

Each of the two conjugated verbs introduce TA-meaning, which interacts between SC and MC, but also probably the selected connective item.

A basic semantic analysis of this type of construction based on the earlier research into Dutch, English, Russian and especially Polish (all earlier references) is provided here for a better understanding as it probably will largely coincide in its generalities, although such an analysis is not the main focus of the current contribution, and a lot more can probably be said about that once the Slovak samples have been thoroughly scrutinized for that purpose. The invariant that has been established, then, consists of the following elements:

- The sinds/since-connective item introduces an SC-event which starts in the past;

- The connective item carries a sense of anteriority, which has to do with the beginning in the past;

- The SC-event sets, one might say, "opens" a temporal frame (the "SC-frame"), which stretches from that beginning in the past up to and including the deictic center, which may be at the moment of utterance or before, but which need not be "filled" entirely/throughout with the SC-event itself;

- The MC-event takes place in the temporal frame set by the SC (although it need not "cover" it exactly);

- There is also a sense of simultaneity in this construction, which comes about as the MC-event takes place against the SC-temporal frame (= at some time in that temporal frame).

${ }^{2}$ The source references are verbatim as they are provided by the Slovak National Corpus prim-8.0-public-sane (hereafter SNK).

${ }^{3}$ Our interlinear glosses follow the Leipzig Glossing Rules. (https://www . eva .mpg . de/lingua/resources/glossing-rules.php). See also our list of abbreviations below.

${ }^{4}$ Please note that in the glosses and translation of examples we have not wanted to pinpoint the exact English aspect-forms. That would be quite impossible and is very dependent on context and a few other factors, which have no bearing on the Slovak originals. 
The whole thing may visually be presented thus:

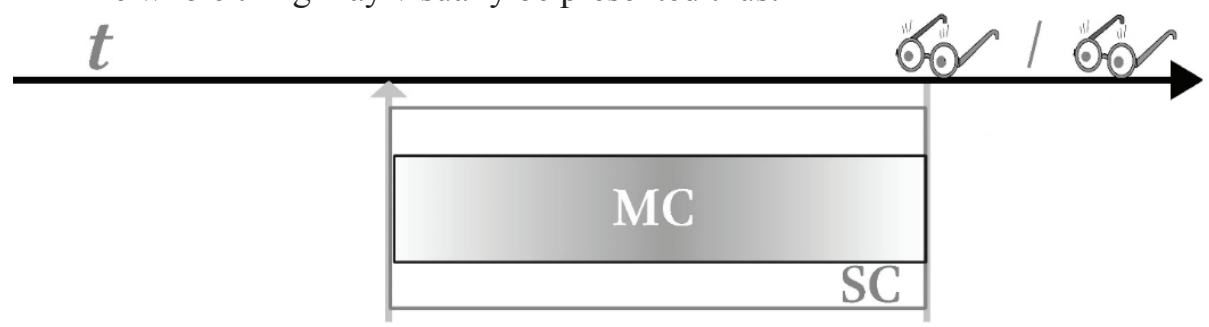

Fig. 1. Invariant meaning of sinds/since constructions (after [9] for Polish)

The spectacles represent the location from which an event is observed and it may or may not coincide with the moment of utterance or come after, depending on the particular TA-constellation used.

\subsection{Sample examples}

The following is a list of examples with more or less randomly chosen sinds/ since-connective items - it was not thought necessary in this paper with its main focus on the quantitative data to provide an example of each TA-constellation for each connective item, although the exchangeability of the items has not yet been studied. You will notice that passive forms have been deselected here, and choices are intended to be as "riskless" as possible, again, because the deeper semantic analysis is beyond the scope of this paper and the following provides a sufficient impression for our present purposes.

Please note, that in Dutch and English (for which latter, cf. [10, p. 91] the temporal location of the SC-event may not be placed in its entirety in the future. SCfuture tenses have not been encountered for Polish and for Slovak they have been omitted here; moreover, they are not likely to fall within the scope of sinds/since and one of our purposes is a comparison with Polish. Please note in this respect that PRS. $\mathrm{PFV}$ is not qualified here as future, although it deictically often functions as such.

\begin{tabular}{|r|l|l|l|l|l|}
\hline \multicolumn{2}{|l|}{ SC } & \multicolumn{2}{l|}{ MC } & example (ex SNK) \\
\hline 1 & PST & PFV & PST & PFV & $\begin{array}{l}\text { (1) Odkedy t'a stretol, všetko sa zmenilo. [LŠti3] } \\
\text { 'Since he (had/has) met you, everything (had/has) changed.' }\end{array}$ \\
\hline 2 & PST & PFV & PST & IPFV & $\begin{array}{l}\text { (2) Od chvile, ked' odišla sanitka, pri Holmbergových nohách } \\
\text { sa chúlil Wurst. [KBlo1] } \\
\text { 'From the moment the ambulance left, Wurst snuggled to } \\
\text { Holmberg's feet.' }\end{array}$ \\
\hline
\end{tabular}

${ }^{5}$ Please note that the English translations in this table are for working purposes only: their TA-constellations will depend on matters at play in English that are beyond the scope of our research here. Only in example (1) have we given a few alternatives to give an impression. Please, note also that example (1) is the same as provided above and so we kept the same number. 


\begin{tabular}{|c|c|c|c|c|c|}
\hline & \multicolumn{2}{|l|}{$\mathrm{SC}$} & \multicolumn{2}{|c|}{ MC } & \multirow{2}{*}{$\begin{array}{l}\text { example (ex SNK) } \\
\text { (3) Sledujeme vás od chvile, čo ste vkročili do močiara } \\
\text { [JČerv3] } \\
\text { 'We've been following you since you stepped into the swamp.' }\end{array}$} \\
\hline 3 & PST & PFV & PRS & IPFV & \\
\hline 4 & PRS & IPFV & PRS & IPFV & $\begin{array}{l}\text { (4) Od tej doby, ako hrávam futbal, viem čo mám robit'. } \\
\text { [MYTR2009/01] } \\
\text { 'Since [*I play] I have been playing football, I know what to } \\
\text { do.' }\end{array}$ \\
\hline 5 & PST & IPFV & PST & PFV & $\begin{array}{l}\text { (5) S nostalgiou si uvedomil, že odvtedy, čo bol bezstarostný } \\
\text { chalan, zmenilo sa mnoho vecí. [EMcb11] } \\
\text { 'With nostalgia, he realized that many things had changed } \\
\text { since he was a carefree boy.' }\end{array}$ \\
\hline 6 & PST & IPFV & PST & IPFV & $\begin{array}{l}\text { (6) Prvý raz odvtedy, čo žil na vel'chánovom dvore, } \\
\text { nesprevádzal cisára na letné sídlo. [WMei1] } \\
\text { 'For the first time since he had been living at court, he did not } \\
\text { escort the emperor to the summer residence.' }\end{array}$ \\
\hline 7 & PRS & IPFV & PST & PFV & $\begin{array}{l}\text { (7) Od tej doby, čo sa zúčastňujem tohto projektu, som sa } \\
\text { naučila vázit'si samu seba. [ASP2002/01] } \\
\text { 'Since I attended this project, I have learned to appreciate } \\
\text { myself.' }\end{array}$ \\
\hline 8 & PST & PFV & PRS & PFV & $\begin{array}{l}\text { (8) A odvtedy, čo ušli trpaslíci, nikto sa neodváži prehl'adávat' } \\
\text { šachty a poklady v hlbinách. [JTol2] } \\
\text { 'And since the dwarves have gone, no one dares to search the } \\
\text { shafts and treasures in the depths.' }\end{array}$ \\
\hline 9 & PRS & IPFV & PST & IPFV & $\begin{array}{l}\text { (9) Nielen bohovia, ale aj l'udia vždy potrebovali smiech } \\
\text { a zadovažovali si ho od tých čias, čo tu existujú, lenže vel'mi } \\
\text { primitívne... [ABed8] } \\
\text { '[...] but also the people always needed laughter and they } \\
\text { obtained it since they existed here }[. . .] \text {...' }\end{array}$ \\
\hline 10 & PST & IPFV & PRS & IPFV & $\begin{array}{l}\text { (10) Ved'odvtedy, ako účinkovali v našom programe, } \\
\text { nepretržite pracujú až dodnes. [MYNO2016/09] } \\
\text { 'After all, ever since they participated in our program, they } \\
\text { have been working [in work] uninterruptedly until today.' }\end{array}$ \\
\hline 11 & PRS & IPFV & PRS & PFV & $\begin{array}{l}\text { (11) Odvtedy, čo navštevujem Grécko, vždy si priveziem } 5 \\
\text { litrov olivového oleja, ... [MYŽN2009/31] } \\
\text { 'Since I have been visiting Greece, I every time bring } 5 \text { liters } \\
\text { of olive oil,...' }\end{array}$ \\
\hline 12 & PST & IPFV & PRS & $P F V$ & $\begin{array}{l}\text { (12) ... ešte vlani ho piekli každý druhý deñ, ale odvtedy, } \\
\text { čo šiel starý Nérer do penzie, zoženieš ho už len v piatok)... } \\
\text { [JJoh2] } \\
\text { ‘.. Last year they bake it every other day, but since old Nerer } \\
\text { went to the pension, you will only get it on Friday)... }\end{array}$ \\
\hline
\end{tabular}

Tab. 1. Sample examples of all researched TA-constellations - random connective items

These 12 examples cover all the basic TA-constellation types and the following further examples are provided to cover the special types that are mentioned for 
Polish [8] and have now been recognized in Slovak. To complete this issue, we will briefly discuss these.

In both the Polish and now also the Slovak dataset, many examples of various TA-constellations occurred with the meaning 'remember'.

(13) Ja od chvíle, čo si pamätám, som vždy cítil potrebu bojovat'. [HN2011/05] 'Me, ever since I can remember / for as long as I can remember, I have always felt the need to fight.'

These are translatable by a sinds/since construction but there the alternative 'for as long as' is usually lacking for other verbs. In terms of taxis this is a noteworthy difference.

Another frequent subtype, for which its distribution across the TA-constellations in Slovak still needs to be studied, might be described as 'the passing of time', cf.(14).

(14)a Zistuje, že ubehlo asi dvadsat' minút od chvile, ked' zdriemol. [LT1998/07] 'He discovers that about twenty minutes have passed since he took a nap.'

A perhaps somewhat unexpected type has future relevance, but is nevertheless translatable with since.

(14)b Dvadsiateho siedmeho decembra uplynie mesiac odvtedy, čo má sadru. [KOR2001/12]

'On the twenty-seventh of December, a month will have passed since he has a cast.'

Not at all surprising is the fact that phase verb 'begin' crops up often in this dataset; the connective's meaning 'since' marks a point at which an event commences. Example (15) is rather special as it has such a phase verb both in SC as in MC.

(15) Narodí sa nám diet'a, no nie diet'a, ktoré jednoducho začne umierat' od chvile, ked' začina žit'. [KRah1]

'A child was born unto us, but not a child who simply begins to die from the moment he begins to live.'

The last of our special mentions is an issue touched upon already by [10] and [7] for English and by o.a. [8], [11] and [12] for Slavic languages. It is the issue of the necessity in many examples for an element in the MC that gives some sort of "weight", some specific "load" or relevance, without which a sentence may be grammatically well-formed, but is nevertheless bad. In (16) the relevant element is underscored. 
(16) Myšlienka na odchod z ostrova mi neskrsla v hlave ani raz od chvíle, čo som na ñom pristál. [YMar1]

'The thought of leaving the island didn't occur to me even once, since I came upon it.'

This concludes the samples and we shall leave the remainder of the semantic analysis for future research: the reader at this point should have a sufficient impression of what is involved with the sinds/since temporal constructions.

In this paper we proceed by describing the methods used for identifying Slovak correspondences to Dutch sinds and English temporal since using the ASPAC parallel aligned corpus and for compiling our data set using the SNK. Further on we present the quantitative data: on that basis we will discuss the statistical analysis and propose a few lines of research to follow up, as ultimately the (future) goal is to make an extensive semantic analysis and establish the set of usage restrictions for each of the individual connective items.

\section{DATA SET, METHODOLOGY}

\subsection{Identification of the correspondences}

As mentioned in 1. the starting point for this research were the Dutch connective item sinds and English since in temporal usage. ${ }^{6}$ As for our earlier research on Polish, $A S P A C$ - Amsterdam Slavic Parallel Aligned Corpus ${ }^{7}$ was used: simple queries via ParaConc yielded the correspondences: odkedy; odvtedy, čo; odvtedy, ako; od chvile, ked'; od chvile, čo; od chvile, ako; od tých čias, čo; od tých čias, ako; od tej doby, čo; od tej doby, ako.

Hereafter we will refer to these as 'connective items' rather than as 'conjunctions' on account of their sometimes complex shape, consisting of more than one lexical element, which are sometimes exchangeable. In this respect it is important to note that this method to identify the connective items deselects such items that fall outside the (semantic and other) scope of the connective items in the source languages. This is important as it has been established ([8], [9]) that at least the Polish connective items are not primarily restricted to use with past deixis such as their Dutch and English counterparts. It was expected - and has indeed been established, cf. the following - that this holds for the Slovak counterparts as well.

${ }^{6}$ The English connective items under scrutiny are since and ever since in their temporal functions only. As was pointed out in [6], [7], [8], [9] and [10] non-temporal since such as we find in e.g. Since I'm a taxi driver, I know how to get there allows for TA-constellations that are at variance with those for temporal (ever) since. Dutch sinds is always temporal.

${ }^{7} A S P A C$ is a non-tagged, restricted access corpus compiled by Adrie Barentsen. It consists of original and translated Slavic literary texts. Cf. http://www.uva.nl/profiel/b/a/a.a. barentsen/a.a.barentsen.html. We are indebted to Barentsen for the access provided. 


\subsection{Strategies for compiling the data set with the SNK}

Our data, once sourced from the SNK, was set out onto a simple Excel-sheet. It was our purpose to classify all corpus search results per connective item and TAconstellation of $\mathrm{MC}$ and $\mathrm{SC}$ taken together. Of the sixteen logically possible combinations, twelve were actually encountered and found to equate sinds/since usage and they are plotted onto tables 1 through 3 . The four possible constellations with SC:PRS.PFV only yielded a very limited number of samples that (for various reasons) never correspond to sinds/since. Obviously the expected future deixis of SC:PRS.PFV, often sets a time frame in the future, which is incompatible with sinds/ since. There are other, not yet researched instances as well: cf. (17) in which there is a kind of generic/repetitive (exemplary) meaning intended.

(17) Väčšina l'udí si o vás vytvorí prvý dojem najneskôr do piatich sekúnd od chvile, ako vás zbadá. [InZ2000/02]

Most people DAT about you make.3sG.PRS.PFV first impression at_most to five seconds from moment that you.ACC notice.3sG.PRS.PFV.

'Most people will have made a first impression within five seconds from the moment they will (have) notice(d) you.'

As such these types have been deselected from this research.

As we were searching the SNK for our connective items, it soon became clear that some search strings yielded many thousands of hits (e.g. 16067 for odkedy alone), whilst others amounted to just a tiny handful of examples. It was decided early on that it would be more practical to have a different treatment for the highly frequent connective items as opposed to the rather lower scoring items; the material for the lower scoring items - od chvile, ako; od tých čias, čo; od tých čias, ako; od tej doby, čo; od tej doby, ako - counted "manually", which means that the TA constellations for both $\mathrm{MC}$ and $\mathrm{SC}$ were classified by the researchers for all hits without searches for tagged grammatical categories. We considered this to be the most accurate way to deal with material with low scores.

The higher scoring connective items - odkedy; odvtedy, čo; odvtedy, ako; od chvile, ked'; od chvile, $\check{c}$ - needed to be sourced, classified and counted via SNK-search strings with specified TA for both MC as well as SC. For this purpose we used the fact that the SNK corpus is tagged for tense as well as for aspect: verbs in PST and PRS are tagged respectively VL.* and VK.*, and PFV and IPFV are tagged V.d.* and V.e.* respectively. The search was done in two tiers to cover the two possible sequence-types of the clauses: SC-MC and MC-SC. The queries for odvtedy, čo, then, are as follows:

Type 1: clause sequence SC:PST.PFV-MC:PST.PFV:

Odvtedy, čo odišli zo Slovenska, už ubehlo desat' rokov. [SME2014/07]

'Since they (had/have) left Slovakia, ten years (had/have) passed.'

- Search CQL: [lemma="odvtedy"] [lemma=","] [lemma="čo"] within $<\mathrm{s} />$ 
- Filter: positive, range $(0,10)$ incl KWIC, CQL: [tag="VLd.*"] [ ] $\{0,5\}$ [word==","] [ ] $\{0,5\}$ [tag="VLd.*"] ${ }^{8}$

Type 2: clause sequence MC:PST.PFV-SC:PST.PFV:

Prešiel už rok odvtedy, čo ocko oslávil pätdesiatiny. [EFBS1]

'A year (has/had) already passed since father (has/had) turned fifty.'

- Search CLQ: [lemma="odvtedy"] [lemma=","] [lemma="čo"] within [tag="VLd.*"] [ ] $\{0,10\}$ [tag="VLd.*"] within $<$ s/>

- Filter: negative, range $(-1,-1)$ excl. KWIC, CQL: lemma $=" . "$

(The filter is applied to ensure the deselection of sentences that begin with the queried string itself when this belongs to the previous sentence in the text.)

For each of the logically possible TA-constellations as well as for each of the identified connective items the above search strings were adjusted.

In the further processing, the "order-types" were not separated out in any of the calculations as the clause order was deemed inconsequential for the present research (although we do not exclude it could be worth researching these variations at a later stage). The totals - and indeed all working figures of the higher scoring items provided in table 1 are then the sum of the scores for these two order-types. The SNK search options allow for other solutions to our problems, but this turned out to be easy enough to apply successfully, although we realize that an "automatic" count is never as precise as the "manual" one, we applied for the lower scoring connective items. Some existing false positive or negative results do affect accuracy of the results but for totals in the order of thousands we consider the statistical error to be low enough for this early study. Further research is needed to establish the exact inaccuracy of similar corpus queries.

In the following we will present the quantitative data.

\begin{tabular}{|c|c|c|c|c|c|c|c|c|c|c|}
\hline \multirow{3}{*}{$\begin{array}{r}\mathrm{nr} \\
1\end{array}$} & \multicolumn{2}{|c|}{$\mathrm{SC}$} & \multicolumn{2}{|c|}{$\mathrm{MC}$} & \multirow{2}{*}{\multicolumn{2}{|c|}{$\begin{array}{c}\text { sum of all } \\
\text { connective items }\end{array}$}} & \multirow{2}{*}{\multicolumn{2}{|c|}{$\begin{array}{c}\text { sum of all } \\
\text { connective items - } \\
\text { odkedy }\end{array}$}} & \multirow{2}{*}{\multicolumn{2}{|c|}{ odkedy }} \\
\hline & \multirow{2}{*}{$\frac{\mathrm{T}}{\mathrm{PST}}$} & \multirow{2}{*}{$\frac{\mathrm{A}}{\mathrm{PFV}}$} & \multirow{2}{*}{$\begin{array}{l}\mathrm{T} \\
\mathrm{PST}\end{array}$} & \multirow{2}{*}{ A } & & & & & & \\
\hline & & & & & 6456 & $26.04 \%$ & 2884 & $32.90 \%$ & 3572 & $22.28 \%$ \\
\hline 2 & $\begin{array}{l}\text { PST } \\
\end{array}$ & PFV & $\begin{array}{l}\text { PST } \\
\end{array}$ & IPFV & 5493 & $22.15 \%$ & 2075 & $23.67 \%$ & 3418 & $21.32 \%$ \\
\hline 3 & PST & PFV & PRS & IPFV & 4119 & $16.61 \%$ & 1382 & $15.76 \%$ & 2737 & $17.07 \%$ \\
\hline 4 & PRS & IPFV & PRS & IPFV & 1859 & $7.50 \%$ & 240 & $2.74 \%$ & 1619 & $10.10 \%$ \\
\hline
\end{tabular}

${ }^{8}$ The limitations on the word range $(=10)$ were set after some experimenting with other ranges. Shorter ranges excluded many usable examples whilst wider ranges introduced inaccuracies in the scores on account of interference from other than the targeted verbs in the sentences. 


\begin{tabular}{|c|c|c|c|c|c|c|c|c|c|c|}
\hline \multirow{3}{*}{$\begin{array}{r}\mathrm{nr} \\
5\end{array}$} & \multicolumn{2}{|l|}{$\mathrm{SC}$} & \multicolumn{2}{|c|}{$\mathrm{MC}$} & \multirow{2}{*}{\multicolumn{2}{|c|}{$\begin{array}{c}\text { sum of all } \\
\text { connective items }\end{array}$}} & \multirow{2}{*}{\multicolumn{2}{|c|}{$\begin{array}{c}\text { sum of all } \\
\text { connective items - } \\
\text { odkedy }\end{array}$}} & \multirow{2}{*}{\multicolumn{2}{|c|}{ odkedy }} \\
\hline & \multirow{2}{*}{$\begin{array}{l}\mathrm{T} \\
\mathrm{PST}\end{array}$} & \multirow{2}{*}{$\begin{array}{l}\mathrm{A} \\
\mathrm{IPFV}\end{array}$} & \multirow{2}{*}{$\begin{array}{l}\mathrm{T} \\
\mathrm{PST}\end{array}$} & \multirow{2}{*}{$\begin{array}{l}\mathrm{A} \\
\mathrm{PFV}\end{array}$} & & & & & & \\
\hline & & & & & 1615 & $6.51 \%$ & 751 & $8.57 \%$ & 864 & $5.39 \%$ \\
\hline 6 & PST & IPFV & PST & IPFV & 1431 & $5.77 \%$ & 419 & $4.78 \%$ & 1012 & $6.31 \%$ \\
\hline 5 & PRS & IPFV & PST & PFV & 1240 & $5.00 \%$ & 87 & $0.99 \%$ & 1153 & $7.19 \%$ \\
\hline 7 & PST & PFV & PRS & PFV & 888 & $3.58 \%$ & 634 & $7.23 \%$ & 254 & $1.58 \%$ \\
\hline 8 & PRS & IPFV & PST & IPFV & 834 & $3.36 \%$ & 33 & $0.38 \%$ & 801 & $5.00 \%$ \\
\hline 9 & PST & IPFV & PRS & IPFV & 659 & $2.66 \%$ & 234 & $2.67 \%$ & 425 & $2.65 \%$ \\
\hline 11 & PRS & IPFV & PRS & PFV & 168 & $0.68 \%$ & 10 & $0.11 \%$ & 158 & $0.99 \%$ \\
\hline 12 & PST & IPFV & PRS & PFV & 35 & $0.14 \%$ & 18 & $0.21 \%$ & 17 & $0.11 \%$ \\
\hline & & & & otals: & 24797 & $100 \%$ & 8767 & $100 \%$ & 16030 & $100 \%$ \\
\hline
\end{tabular}

\begin{tabular}{|c|c|c|c|c|c|c|c|c|c|c|}
\hline \multirow{3}{*}{$\begin{array}{r}\mathrm{nr} \\
1\end{array}$} & \multicolumn{2}{|l|}{$\mathrm{SC}$} & \multicolumn{2}{|c|}{$\mathrm{MC}$} & \multirow{2}{*}{\multicolumn{2}{|c|}{ odvtedy, čo }} & \multirow{2}{*}{\multicolumn{2}{|c|}{ odvtedy, ako }} & \multirow{2}{*}{\multicolumn{2}{|c|}{ od chvíle, ked' }} \\
\hline & \multirow{2}{*}{$\begin{array}{l}\mathrm{T} \\
\text { PST }\end{array}$} & \multirow{2}{*}{$\frac{\mathrm{A}}{\mathrm{PFV}}$} & \multirow{2}{*}{$\frac{\mathrm{T}}{\mathrm{PST}}$} & \multirow{2}{*}{$\begin{array}{l}\mathrm{A} \\
\mathrm{PFV}\end{array}$} & & & & & & \\
\hline & & & & & 1407 & $32.32 \%$ & 499 & $29.72 \%$ & 455 & $40.23 \%$ \\
\hline 2 & PST & $\mathrm{PFV}$ & PST & IPFV & 716 & $16.45 \%$ & 381 & $22.69 \%$ & 400 & $35.37 \%$ \\
\hline 3 & PST & PFV & PRS & IPFV & 709 & $16.29 \%$ & 352 & $20.96 \%$ & 102 & $9.02 \%$ \\
\hline 4 & PRS & IPFV & PRS & IPFV & 113 & $2.60 \%$ & 67 & $3.99 \%$ & 9 & $0.80 \%$ \\
\hline 5 & PST & IPFV & PST & PFV & 460 & $10.57 \%$ & 115 & $6.85 \%$ & 103 & $9.11 \%$ \\
\hline 6 & PST & IPFV & PST & IPFV & 241 & $5.54 \%$ & 84 & $5.00 \%$ & 21 & $1.86 \%$ \\
\hline 7 & PRS & IPFV & PST & PFV & 34 & $0.78 \%$ & 38 & $2.26 \%$ & & \\
\hline 8 & PST & PFV & PRS & $\mathrm{PFV}$ & 507 & $11.65 \%$ & 72 & $4.29 \%$ & 22 & $1.95 \%$ \\
\hline 9 & PRS & IPFV & PST & IPFV & 18 & $0.41 \%$ & 5 & $0.30 \%$ & 1 & $0.09 \%$ \\
\hline 10 & PST & IPFV & PRS & IPFV & 138 & $3.17 \%$ & 61 & $3.63 \%$ & 7 & $0.62 \%$ \\
\hline 11 & PRS & IPFV & PRS & PFV & 6 & $0.14 \%$ & & $0.00 \%$ & 3 & $0.27 \%$ \\
\hline 12 & PST & IPFV & PRS & PFV & 4 & $0.09 \%$ & 5 & $0.30 \%$ & 8 & $0.71 \%$ \\
\hline & & & & otals: & 4353 & $100 \%$ & 1679 & $100 \%$ & 1131 & $100 \%$ \\
\hline
\end{tabular}

\begin{tabular}{|c|c|c|c|c|c|c|c|c|c|c|}
\hline \multirow{3}{*}{$\begin{array}{r}\mathrm{nr} \\
1\end{array}$} & \multicolumn{2}{|l|}{$\mathrm{SC}$} & \multicolumn{2}{|c|}{$\mathrm{MC}$} & \multirow{2}{*}{\multicolumn{2}{|c|}{ od chvíle, čo }} & \multirow{2}{*}{\multicolumn{2}{|c|}{ od chvíle, ako }} & \multirow{2}{*}{\multicolumn{2}{|c|}{ od tých čias, čo }} \\
\hline & \multirow{2}{*}{$\begin{array}{l}\mathrm{T} \\
\mathrm{PST}\end{array}$} & \multirow{2}{*}{$\frac{\mathrm{A}}{\mathrm{PFV}}$} & \multirow{2}{*}{$\begin{array}{c}\mathrm{T} \\
\text { PST }\end{array}$} & \multirow{2}{*}{$\frac{\mathrm{A}}{\mathrm{PFV}}$} & & & & & & \\
\hline & & & & & 218 & $44.86 \%$ & 159 & $27.46 \%$ & 82 & $24.19 \%$ \\
\hline 2 & PST & PFV & PST & IPFV & 175 & $36.01 \%$ & 264 & $45.60 \%$ & 88 & $25.96 \%$ \\
\hline 3 & PST & PFV & PRS & IPFV & 23 & $4.73 \%$ & 109 & $18.83 \%$ & 44 & $12.98 \%$ \\
\hline 4 & PRS & IPFV & PRS & IPFV & 6 & $1.23 \%$ & 7 & $1.21 \%$ & 24 & $7.08 \%$ \\
\hline
\end{tabular}




\begin{tabular}{|c|c|c|c|c|c|c|c|c|c|c|}
\hline \multirow{3}{*}{$\frac{\mathrm{nr}}{5}$} & \multicolumn{2}{|c|}{$\mathrm{SC}$} & \multicolumn{2}{|c|}{$\mathrm{MC}$} & \multirow{2}{*}{\multicolumn{2}{|c|}{ od chvíle, čo }} & \multirow{2}{*}{\multicolumn{2}{|c|}{ od chvíle, ako }} & \multirow{2}{*}{\multicolumn{2}{|c|}{ od tých čias, čo }} \\
\hline & \multirow{2}{*}{$\begin{array}{l}\mathrm{T} \\
\text { PST }\end{array}$} & \multirow{2}{*}{$\frac{\mathrm{A}}{\mathrm{IPFV}}$} & \multirow{2}{*}{$\begin{array}{l}\mathrm{T} \\
\mathrm{PST}\end{array}$} & \multirow{2}{*}{$\frac{\mathrm{A}}{\mathrm{PFV}}$} & & & & & & \\
\hline & & & & & 21 & $4.32 \%$ & 9 & $1.55 \%$ & 32 & $9.44 \%$ \\
\hline 6 & PST & IPFV & PST & IPFV & 15 & $3.09 \%$ & 18 & $3.11 \%$ & 37 & $10.91 \%$ \\
\hline 7 & PRS & IPFV & PST & PFV & & & 2 & $0.35 \%$ & 10 & $2.95 \%$ \\
\hline 8 & PST & PFV & PRS & PFV & 24 & $4.94 \%$ & 8 & $1.38 \%$ & & \\
\hline 9 & PRS & IPFV & PST & IPFV & 1 & $0.21 \%$ & & $0.00 \%$ & 5 & $1.47 \%$ \\
\hline 10 & PST & IPFV & PRS & IPFV & 3 & $0.62 \%$ & 3 & $0.52 \%$ & 15 & $4.42 \%$ \\
\hline 11 & PRS & IPFV & PRS & PFV & & & & $0.00 \%$ & 1 & $0.29 \%$ \\
\hline 12 & PST & IPFV & PRS & PFV & & & & $0.00 \%$ & 1 & $0.29 \%$ \\
\hline & & & & otals: & 486 & $100 \%$ & 579 & $100 \%$ & 339 & $100 \%$ \\
\hline
\end{tabular}

\begin{tabular}{|c|c|c|c|c|c|c|c|c|c|c|}
\hline \multirow{3}{*}{$\begin{array}{r}\mathrm{nr} \\
1\end{array}$} & \multicolumn{2}{|c|}{$\mathrm{SC}$} & \multicolumn{2}{|c|}{$\mathrm{MC}$} & \multirow{2}{*}{\multicolumn{2}{|c|}{ od tých čias, ako }} & \multirow{2}{*}{\multicolumn{2}{|c|}{ od tej doby, čo }} & \multirow{2}{*}{\multicolumn{2}{|c|}{ od tej doby, ako }} \\
\hline & \multirow{2}{*}{$\frac{\mathrm{T}}{\mathrm{PST}}$} & \multirow{2}{*}{$\frac{\mathrm{A}}{\mathrm{PFV}}$} & \multirow{2}{*}{$\frac{\mathrm{T}}{\text { PST }}$} & \multirow{2}{*}{$\frac{\mathrm{A}}{\mathrm{PFV}}$} & & & & & & \\
\hline & & & & & 36 & $30.77 \%$ & 22 & $30.99 \%$ & 6 & $50.00 \%$ \\
\hline 2 & PST & PFV & PST & IPFV & 32 & $27.35 \%$ & 19 & $26.76 \%$ & & \\
\hline 3 & PST & PFV & PRS & IPFV & 24 & $20.51 \%$ & 15 & $21.13 \%$ & 4 & $33.33 \%$ \\
\hline 4 & PRS & IPFV & PRS & IPFV & 5 & $4.27 \%$ & 7 & $9.86 \%$ & 2 & $16.67 \%$ \\
\hline 5 & PST & IPFV & PST & PFV & 10 & $8.55 \%$ & 1 & $1.41 \%$ & & \\
\hline 6 & PST & IPFV & PST & IPFV & 3 & $2.56 \%$ & & $0.00 \%$ & & \\
\hline 7 & PRS & IPFV & PST & PFV & 2 & $1.71 \%$ & 1 & $1.41 \%$ & & \\
\hline 8 & PST & PFV & PRS & PFV & 1 & $0.85 \%$ & & $0.00 \%$ & & \\
\hline 9 & PRS & IPFV & PST & IPFV & 3 & $2.56 \%$ & & $0.00 \%$ & & \\
\hline 10 & PST & IPFV & PRS & IPFV & 1 & $0.85 \%$ & 6 & $8.45 \%$ & & \\
\hline 11 & PRS & IPFV & PRS & PFV & & & & $0.00 \%$ & & \\
\hline 12 & PST & IPFV & PRS & PFV & & & & $0.00 \%$ & & \\
\hline & & & & totals & 117 & $100 \%$ & 71 & $100 \%$ & 12 & $100 \%$ \\
\hline
\end{tabular}

Tab. 2. Quantitative data sourced from the SNK, processed in Excel

\section{DISCUSSION OF THE QUANTITATIVE DATA}

\subsection{Slovak connective item}

The numbers of SNK-hits were set out onto an Excel sheet and calculations were made to produce totals and percentages. Table 2 shows the results of this rounded off to two decimal places. The connective items are set out according to 
frequency from left to right. The TA-constellations across $\mathrm{SC}$ and $\mathrm{MC}$ are sorted according to frequency from top to bottom of the total occurrence of each TAconstellation. In this way the preponderance/preference of each connective item per TA-constellation can be easily judged. For better legibility we have refrained from marking zero (and $0.00 \%$ ) scores.

It will be apparent that of the logically possible TA-constellations four are missing and this was discussed in 2.2 above.

The data shows that odkedy is by far the most highly scoring connective item not only in total, but also in all constellation types, and even, albeit with the notable exception of type 7 (and less notably 12), in absolute numbers against the sums of the scores of the other connective items taken together. Its frequency of occurrence, however, does not trace that of the totals for all connective items together - even though those totals are of course heavily influenced by odkedy itself. For this reason as well as its unevenly high score we have produced a further column with totals for all connective items except odkedy. The differences between odkedy-scores against this column are even greater - as expected - and they display some interesting features which will be pointers for future research. For now we want to point out that our research has so far not produced any evidence that the respective connective items should not be exchangeable in any clear way and so we cannot at this point in time pinpoint why, in what circumstances a particular connective item is preferred. Here we can only mention in which TA-constellation there are significant deviations of odkedy against the others. The following table 3 shows this.

\begin{tabular}{|l|l|l|l|l|r|c|}
\hline \multirow{2}{*}{$\mathrm{nr}$} & \multicolumn{3}{|l|}{$\mathrm{SC}$} & \multicolumn{2}{|l|}{ MC } & sum of all connective \\
items - odkedy & odkedy
\end{tabular}

others outscored by odkedy

\begin{tabular}{|r|l|l|l|l|r|r|r|r|}
\hline 4 & PRS & IPFV & PRS & IPFV & 240 & $2.74 \%$ & 1619 & $10.10 \%$ \\
\hline 7 & PRS & IPFV & PST & PFV & 87 & $0.99 \%$ & 1153 & $7.19 \%$ \\
\hline 9 & PRS & IPFV & PST & IPFV & 33 & $0.38 \%$ & 801 & $5.00 \%$ \\
\hline
\end{tabular}

odkedy outscored by others

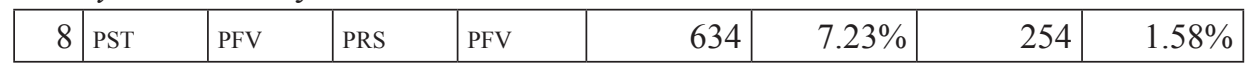

Tab. 3. Quantitative data sourced from the SNK, processed in Excel

Apart from the anyway very low scoring od tej doby, čo and od tej doby, ako, the other items have a preponderance for especially type 5 (SC:PST.IPFV-MC:PST.PFV) and most, but notably not od tých čias, čo; od tých čias, ako; od tej doby, čo; od tej doby, ako also for type 8 (SC:PST.PFV-MC:PRS.PFV). 
The choice of connective item seems to only be very slightly influenced or determined by the TA-constellation with only a few "preferences". To date we have, pending our semantic analysis of the data, not conclusively established why these preferences occur and why the distribution of all connective items is not more even, especially that of odkedy.

\subsection{Sum of all connective items: Slovak \& Polish}

We took the sum of the occurrences in our data set of each of the researched TA-constellations with $\mathrm{SC}+\mathrm{MC}$ taken together and compared that data with similar data for Polish, the only language for which such data is at hand. As the purpose of this research was to establish line of further research, it seemed relevant to do so and learn what we could: significant differences would pinpoint ares for further research. That yielded table $4 .{ }^{9}$

\begin{tabular}{|c|c|c|c|c|c|c|c|c|}
\hline \multirow{3}{*}{$\begin{array}{r}\mathrm{nr} \\
1 \\
\end{array}$} & \multicolumn{2}{|l|}{$\mathrm{SC}$} & \multicolumn{2}{|l|}{$\mathrm{MC}$} & \multirow{2}{*}{\multicolumn{2}{|c|}{ Slovak }} & \multirow{2}{*}{\multicolumn{2}{|c|}{ Polish }} \\
\hline & \multirow{2}{*}{$\begin{array}{l}\mathrm{T} \\
\text { PST } \\
\end{array}$} & \multirow{2}{*}{$\begin{array}{l}\text { A } \\
\text { PFV }\end{array}$} & \multirow{2}{*}{\begin{tabular}{|l}
$\mathrm{T}$ \\
PST
\end{tabular}} & \multirow{2}{*}{\begin{tabular}{|l} 
A \\
PFV
\end{tabular}} & & & & \\
\hline & & & & & 6456 & $26.04 \%$ & 431 & $31.23 \%$ \\
\hline 2 & PST & PFV & PST & IPFV & 5493 & $22.15 \%$ & 324 & $23.48 \%$ \\
\hline 3 & PST & PFV & PRS & IPFV & 4119 & $16.61 \%$ & 241 & $17.46 \%$ \\
\hline 4 & PRS & IPFV & PRS & IPFV & 1859 & $7.50 \%$ & 115 & $8.33 \%$ \\
\hline 5 & PRS & IPFV & PST & PFV & 1240 & $5.00 \%$ & 52 & $3.77 \%$ \\
\hline 6 & PST & IPFV & PST & IPFV & 1431 & $5.77 \%$ & 61 & $4.42 \%$ \\
\hline 7 & PST & IPFV & PST & PFV & 1615 & $6.51 \%$ & 70 & $5.07 \%$ \\
\hline 8 & PRS & IPFV & PST & IPFV & 834 & $3.36 \%$ & 51 & $3.70 \%$ \\
\hline 9 & PST & IPFV & PRS & IPFV & 659 & $2.66 \%$ & 21 & $1.52 \%$ \\
\hline 10 & PST & PFV & PRS & PFV & 888 & $3.58 \%$ & 12 & $0.87 \%$ \\
\hline 11 & PRS & IPFV & PRS & PFV & 168 & $0.68 \%$ & 2 & $0.14 \%$ \\
\hline 12 & PST & IPFV & PRS & PFV & 35 & $0.14 \%$ & 0 & $0.00 \%$ \\
\hline & & & & totals: & 24797 & $100 \%$ & 1380 & $100 \%$ \\
\hline
\end{tabular}

Tab. 4. Sum of all TA-constellations Slovak and Polish [9]

It is rather satisfying - although not entirely unexpected - that Slovak and Polish display virtually the same percentages per TA-constellation. The deviations have been marked in the table by the outline and this concerns types 5, 6 and 7 but they are very slight indeed.

${ }^{9}$ This data is sourced from [9], who also presented scores for SC:PRS.PFV items. The latter has been omitted in this table, which presents, then, a direct comparison of the TA-constellation types for the complex sentences for these two languages. 
Of course, the Polish dataset was considerably smaller, but that should not deter us from suggesting that these two languages have a very similar treatment in terms of TA-constellation of the sinds/since construction.

\subsection{Comparing SC and MC scores: Slovak \& Polish}

Next, we considered the TA-data per clause and so with the scores and percentages for all connective items taken together. In the following two tables 5 the scores for all SC have been summed regardless of the MC they are combined with. Also the tables display the scores for all $\mathrm{MC}$ regardless of their SC.

\begin{tabular}{|c|c|c|c|c|c|c|c|}
\hline \multicolumn{4}{|c|}{ SC } & \multicolumn{4}{|l|}{$\mathrm{MC}$} \\
\hline $\mathrm{T}$ & $\mathrm{A}$ & score & perc. & $\mathrm{T}$ & $\mathrm{A}$ & score & perc. \\
\hline PST & PFV & 16956 & $68.38 \%$ & & & & \\
\hline PRS & IPFV & 4101 & $16.54 \%$ & & & & \\
\hline PST & IPFV & 3740 & $15.08 \%$ & & & & \\
\hline$P R S$ & $P F V$ & omitted & - & & & & \\
\hline & & & & PST & PFV & 9311 & $37.55 \%$ \\
\hline & & & & PST & IPFV & 7758 & $31.29 \%$ \\
\hline & & & & PRS & IPFV & 6637 & $26.77 \%$ \\
\hline & & & & PRS & PFV & 1091 & $4.40 \%$ \\
\hline & trol total: & 24797 & $100 \%$ & & & 24797 & $100 \%$ \\
\hline
\end{tabular}

Tab. 5a. SC resp. MC: Slovak

This particular Slovak data can at this time be compared to similar quantitative data for Polish, the only other language for which it is available even though the latter is based on considerably smaller quantities of samples. The figures provided by [9] have been adapted to the following table formatted for easy comparison.

\begin{tabular}{|c|c|c|c|c|c|c|c|}
\hline \multicolumn{4}{|l|}{$\overline{\mathrm{SC}}$} & \multicolumn{4}{|l|}{$\mathrm{MC}$} \\
\hline $\mathrm{T}$ & A & score & perc. & $\mathrm{T}$ & A & score & perc. \\
\hline PST & PFV & 1008 & $72.41 \%$ & & & & \\
\hline PRS & IPFV & 220 & $15.80 \%$ & & & & \\
\hline PST & IPFV & 152 & $10.92 \%$ & & & & \\
\hline PRS & PFV & 12 & $0.86 \%$ & & & & \\
\hline & & & & PST & PFV & 553 & $39.73 \%$ \\
\hline & & & & PST & IPFV & 438 & $31.47 \%$ \\
\hline & & & & PRS & IPFV & 387 & $27.80 \%$ \\
\hline & & & & PRS & PFV & 14 & $1.01 \%$ \\
\hline & trol total: & 1392 & $100 \%$ & & & 1392 & $100 \%$ \\
\hline
\end{tabular}

Tab. 5b. SC resp. MC: Polish (cf. [9]) 
In spite of the difference in sample volumes as well as the fact that for Slovak SC:PRS.PFV has been omitted, ${ }^{10}$ we may at this time, however, signal that the scores of the types in percentages are very similar indeed.

\section{CONCLUSIONS}

As stated above in the introduction, the purpose of this paper is to set out further lines of research concerning Slovak correspondences of Dutch/English temporal sinds/since sentences: TA-constellations and connective items. We have utilized the $A S P A C$ and the $S N K$ corpora to compile a dataset and on the quantitative data thus at hand, we propose the following notes in respect to future research:

- Both in Polish and Slovak the types with PRS.PFV (be it in SC or MC) are rare. Although in these languages the sinds/since correspondences were found not to be restricted to past deixis, nevertheless it would seem that connective items such as those under discussion still have a prepondering use for past deixis. The PRS.PFV types need to be further researched to establish the extent of their usage as well as the functioning of the TA-constellations. NB. The particular "exemplary" use of PRS.PFV in (17) certainly needs further research and future deixis does not seem obvious.

This will aid formulating the very definition of the Slovak (and indeed Polish) connective items and their usage.

- The comparison of Slovak vs. Polish data shows that these two languages do not differ significantly in TA-constellations encountered for sinds/since complex sentences. There are a few points at which there are small differences and one might surmise that these are due to as yet not researched differences in the respective TA systems of these languages.

- The meaning types of the TA-constellations need to be established more precisely for Slovak (such as has been done e.g. for Polish in [9]).

- The preference(s) for particular TA-constellations by the individual connective items needs further research. An inroad into this will be the outlying scores in our table 2 and also 3 . This will further establish the preferred meaning type(s) but also pinpoint the meaning and usage of the connective items.

- In our research to date on Slovak we have not considered register and clause order (SC-MC vs MC-SC) as factors in the selection of particular connective items. There are, however, some indications from closely related Czech set out by [5] that such matters are not without their significance in the choice of connective item. This still needs to be followed up for Slovak.

In future contributions the present authors intend to address some of these matters, especially the semantic analysis.

\footnotetext{
${ }^{10}$ Although precise counts are not available at this time, it is clear that they are very slight indeed.
} 


\section{ABBREVIATIONS}

$3 \mathrm{SG}=$ third person singular; $\mathrm{ACC}=$ accusative; $\mathrm{ASPAC}$ see below under corpora; $\mathrm{DAT}=$ dative; $\mathrm{IPFV}=$ imperfective; $\mathrm{M}=$ masculine; $\mathrm{MC}=$ main clause $; \mathrm{N}=$ neuter; $\mathrm{PFV}$ $=$ perfective; $\mathrm{PST}=$ past tense; $\mathrm{REFL}=$ reflexive pronoun; $\mathrm{SC}=$ secondary clause; $\mathrm{SNK}$ see below under corpora; $\mathrm{TA}=$ tense-aspect.

\section{References}

[1] Barentsen, A. (2009). Taksis v niderlandskom jazyke. In Tipologija taksisnyx konstrukcij, pages 269-366, V. S. Xrakovskij. Moskva, Znak.

[2] Barentsen, A. (2016). Taxis in Dutch. In Typology of Taxis Constructions (= LINCOM Studies in Theoretical Linguistics 58), pages 205-276, V. S. Xrakovskij. München, Lincom.

[3] Barentsen, A. (2017). Nekotorye nabljudenija o niderlandskom i anglijskom sojuzax sinds/ since i ix sootvetstvijax v sovremennyx slavjanskix jazykax. In Definitely Perfect: Festschrift for Janneke Kalsbeek (= Pegasus Oost-Europese Studies 29), pages 21-56. Eds. R. M. Genis, E. de Haard and R. Lučić. Amsterdam, Uitgeverij Pegasus.

[4] Barentsen, A. (2018). O funkcionirovanii vidovremennyx form v složnyx predloženijax s sojuzom tipa s tex por kak / depuis que: na materiale slavjanskix i neslavjanskix jazykov. In La relation temps/aspect: approches typologique et contrastive (Collection travaux et recherches UL3 / Éditions du Conseil Scientifique de l'Université de Lille 3), pages 153157, T. Milliaressi. Lille, Université Charles-de-Gaulle - Lille3.

[5] Duijkeren-Hrabová, M. van (2017). Het probleem van variatie bij Tsjechische voegwoorden met de betekenis 'sinds'. In Definitely Perfect: Festschrift for Janneke Kalsbeek (= Pegasus Oost-Europese Studies 29), pages 107-128. Eds. R. M. Genis, E. de Haard and R. Lučić. Amsterdam, Uitgeverij Pegasus.

[6] Fijn van Draat, P. (1903). The loss of the prefix ge- in the modern English verb and some of its consequences - The conjunction since. Englische Studien, 32, pages 371-388.

[7] Fryd, M. (2011). Since when is the Present Tense ruled out with SINCE! Groninger Arbeiten zur germanistischen Linguistik, 53(2), pages 89-103.

[8] https://ugp.rug.nl/GAGL/article/view/30529/27829.

[9] Genis, R. M. (2018). Towards a semantic model for conjunctions of 'since' and its interaction with verbal aspect: Polish material. In La relation temps/aspect: approches typologique et contrastive (Collection travaux et recherches UL3 / Éditions du Conseil Scientifique de l'Université de Lille 3), pages 159-163, T. Milliaressi. Lille, Université Charles-de-Gaulle - Lille3.

[10] Genis, R. M. (2019 to appear). Temporal 'since' in Polish: conjunctions \& tense-aspect constellations. In Dutch Contributions to the Sixteenth International Congress of Slavists Linguistics: Belgrade, Belgrade, August 22-27, 2018 (= Studies in Slavic and General Linguistics 44), pages [to appear]. Leiden, Brill - Rodopi.

[11] Heinämäki, O. (1978). Semantics of English Temporal Connectives. Indiana, Indiana University Linguistics Club.

[12] Popović, Lj. (2012). Kontrastivna gramatika srpskog i ukrajinskog jezika: taksis i evidencijalnost. Beograd, Srpska akad. nauka i umetnosti. 
[13] Zorixina-Nil'sson, N. V. (2011). Semantika perfektnosti i dlitel'nosti i sposoby ee vyraženija v vyskazyvanijax s sojuzom s tex por kak (Iz sopostavitel'no-tipologičeskix nabljudenij). In Sistemnye svjazi $v$ grammatike i tekste. Materialy čtenij pamjati Ju. A. Pupynina. 30 aprelja 2010 g. M. D. Voejkova, A. Ju. Pupynina, M. Ju. Pupynina, pages 81-125. Sankt-Peterburg, Nestor - Istorija.

[14] ASPAC $=$ Amsterdam Slavic Parallel Aligned Corpus. Information on the corpus accessible at: http://www.uva.nl/profiel/b/a/a.a.barentsen/a.a.barentsen . html

[15] SNK = Slovenský národný korpus - prim-8.0-public-sane. Bratislava, Jazykovedný ústav L. Štúra SAV 2018. Accessible at: http: / / korpus.juls. savba.sk 